\title{
Effects of Conventional Pesticides on the Preimaginal Developmental Stages and on Adults of Trichogramma cordubensis (Hymenoptera: Trichogrammatidae)
}

\author{
ANTÓNIO VIEIRA, LUÍSA OLIVEIRA AND PATRÍCIA GARCIA \\ Departamento de Biologia, Universidade dos Açores, P-9502 Ponta Delgada \\ Codex, Açores, Portugal
}

(Received for publication 19 July 2000; revised manuscript accepted 8 February 2001)

The effects of seven pesticides sprayed on hosts with parasitoids at different phase so egg to adult development $(24,24-48,48-72,72-96,120-144,192-216$ h) of Trichogramma cordubensis (Vargas \& Cabello) were studied. The effect of these pesticides on the mortality of adult parasitoids upon contact with the hosts immediately or $24 \mathrm{~h}$ after the treatments was also tested. One organophosphat e insecticide (trichlorfon), one organochlorine insecticide (endosulfan), two pyrethroids (deltamethrin and lambda-cyhalothrin), a commercial formulation of Bacillus thuringiensis subsp. Kurstaki, and two fungicides (acetamide + dithiocarbamete and basic copper sulphate) were selected for testing. All the tests were carried out with fresh solutions of commercial insecticides applied on host eggs at the recommended concentration. The pesticides applied at different development phases did not affect the duration of parasitoid development, except endosulfan, which delayed the parasitoid preimaginal development for one day. With few exceptions, the number of parasitized host eggs that turned black (i.e. with parasitoid prepupae) did not differ significantly between the pesticide treatments and the control. The chemical insecticides affected the adult emergence rates significantly, while the other products resulted in emergence rates similar to control values. The longevity of adult progeny was very short when endosulfan or trichlorfon $(<1$ and $<2$ days, respectively) were applied. Overall, endosulfan was the pesticide most harmful to the preimaginal development stages of $\mathrm{T}$. cordubensis. Therefore, the use of this product should be avoided when this species is part of an integrated pest control programme.

Keywords: Trichogramma cordubensis, insecticides, fungicides, toxicity

\section{INTRODUCTION}

Natural enemies of lepidopteran agricultural pests such as Autographa gamma (L.), Chrysodeixis chalcites (Esper), Helocoverpa armigera (Hübner), Noctua pronuba (L.), Peridroma sausia (Hübner), Phlogophora meticulosa (L.), Pseudaletia unipuncta (Haworth), Spodoptera 
littoralis (Boisduval) and Pieris brassicae (L.) can be a key component for their management. Trichogramma cordubensis Vargas \& Cabello is one of the most important parasitoids of these lepidopteran pests on the island of São Miguel-Azores (Portugal) (Garcia et al., 1994; Garcia, 1995). Low rates of parasitism have been reported in several agricultural regions and this may be due partly to the extensive use of insecticides (Gullan \& Cranston, 1992; Driesche \& Bellows, 1996). To promote integrated pest control methods in Azorean crops, where the use of pesticides cannot be completely excluded, efforts have been undertaken to evaluate the safety of the most frequently used pesticides for potential native natural enemies of these lepidopteran agricultural pests, such as T. cordubensis.

Although a wide range of literature is available on the effects of pesticides on Trichogramma (Jalali \& Singh, 1993; Kumar et al., 1994; Branco \& França, 1995; Kring \& Smith, 1995; Sterk et al., 1999) little is known about the lethal effects of pesticides on T. cordubensis.

In this study, the effects of seven different pesticides on the following biological parameters of $T$. cordubensis are examined and compared: adult mortality, duration of preimaginal development, number of parasitized host eggs that turned black, adult emergence rates and the longevity of adult progeny.

\section{MATERIALS AND METHODS}

\section{Insects}

Adults of T. cordubensis were collected originally from São Miguel Island, Azores (Portugal) (Garcia, 1995), and maintained on Ephestia kuehniella Zeller (Lepidoptera: Pyralidae) eggs for the previous 8 years in laboratory conditions, according to the methods of Tavares and Vieira (1992).

\section{Insecticides}

All the tests were done with fresh solutions of commercial pesticides prepared in water. Five insecticides (one organophosphate, one organochlorine, two pyrethroids and a commercial formulation of Bacillus thuringiensis) and two fungicides (acetamide + dithiocarbamete and basic copper sulphate) were tested at the concentrations indicated in Table 1. Pesticides for testing were selected on the basis of their use for the control of different pests in agricultural fields in the Azores archipelago, and concentrations were those recommended by the manufacturer for the control of lepidopteran and fungal pests.

\section{Bioassay 1}

In order to test the effects of various pesticides on the immature stages of $T$. cordubensis, 280 yellow cards $(1.5 \times 0.8 \mathrm{~cm})$ were prepared, each with 500 E. kuehniella eggs glued to it. Each egg card was exposed to 15 females of $T$. cordubensis and placed inside a glass tube $(7 \times 1 \mathrm{~cm})$ for $24 \mathrm{~h}$. Forty cards with E. kuehniella eggs, $<24 \mathrm{~h}$ after parasitization, were

TABLE 1. Details of pesticides tested against $T$. cordubensis

\begin{tabular}{lcccc}
\hline Active ingredient & Pesticide & Formulation & $\begin{array}{c}\text { Concentration } \\
\text { tested (\%) }\end{array}$ & Company \\
\hline Trichlorfon & Diptrex 80 & $80 \%$ PS & 0.20 & Bayer \\
Endosulfan & Thiodan & $35 \%$ EC & 0.65 & Sapec \\
Deltamethrin & Decis & $2.8 \%$ EC & 0.05 & Hoechst \\
Lambda-cyhalothrin & Karate & $5.5 \%$ EC & 0.05 & Zeneca Agro \\
Bacillus thuringiensis & & & 0.10 & Bayer \\
$\quad$ Berliner subsp. Kurstaki & Dipel & 16000 UI WP & 0.25 & Bayer \\
Acetamide+dithiocarbamete & Milraz & $4.8+58 \%$ SP & 2.50 & Quimigal \\
Basic copper sulphate & Calda bordalesa & $25 \%$ SP & & \\
Distilled water & Control & & \\
\hline
\end{tabular}


each sprayed with $6 \mathrm{ml}$ of an aqueous suspension of one of the insecticides using Potter tower equipment (Burkard, Rickmansworth, UK) at 2 bar. Controls were sprayed with distilled water. This resulted in homogeneous spray coverage of $9.52 \pm 2.17 \mu \mathrm{l}$ (mean $\pm \mathrm{SD}$ ) of fluid per $\mathrm{cm}^{2}$, corresponding to the concentrations recommended by the manufacturer (1000 1/ha. Egg cards 24-48, 48-72, 72-96, 120-144, 192-216 h after parasitization were treated similarly. The effects of the treatments on the development times of the parasitoid, on the number of parasitized host eggs that turned black (i.e. with parasitoid prepupae), on the adult emergence rates and on adult longevity were recorded. Each treatment was repeated four times, and there were five replicate cards in each treatment (i.e. $n=20$ egg cards per each treatment).

\section{Bioassay 2}

In order to test the effect of the various pesticides on the mortality of adults of T. cordubensis, 80 egg cards, prepared as described in Bioassay 1, were each sprayed with one of the same seven pesticides or with water (control). After egg cards had dried, $24 \mathrm{~h}$ after spraying, 15 $T$. cordubensis females were introduced into the glass tube containing the treated hosts. Each treatment was repeated four times, and there were five replicate cards in each treatment (i.e. $n=20$ egg cards per each treatment). Mortality of the parasitoid adults was observed 6, 24 and $48 \mathrm{~h}$ after the first contact with the hosts. During the first $24 \mathrm{~h}$, parasitoids were in contact with the treated eggs. After being in contact with the hosts, parasitoids were kept in the same tubes but without the hosts, supplied only with honey solution, for another period of $24 \mathrm{~h}$.

All tests were done under controlled conditions, at $22 \pm 1^{\circ} \mathrm{C}, 70 \pm 5 \%$ relative humidity $(\mathrm{RH})$ and with a photoperiod of $16 \mathrm{~L}: 8 \mathrm{D} \mathrm{h}$.

\section{Statistical Analysis}

Differences in parasitoid development times, number of parasitized host eggs that turned black and adult longevity were determined by ANOVA using $\sqrt{(x+0.5)}$-transformed data. Adult emergence rates and parasitoid mortality (Bioassay 2) were analysed by ANOVA using arcsine $\sqrt{x}$-transformed data (Zar, 1996). When ANOVA showed significant differences $(P<0.05)$ among the means, paired comparisons of each mean were made using StudentNewman-Keuls tests (Zar, 1996). Parasitoid mortality, after contact with the pesticides, was analysed by ANOVA using arcsine $\sqrt{x}$-transformed data. All analyses were performed using SPSS 6.1 (Norusis, 1994) for the Macintosh system.

\section{RESULTS}

\section{Bioassay 1}

The treatments applied at different development phases did not affect the duration of parasitoid development significantly (of approximately 13 days) (Table 2). However, with endosulfan, the preimaginal development was delayed for one day, but the sample size was too small to conclude if there was a significant difference (Table 2).

With few exceptions, pesticides did not significantly affect the number of parasitized host eggs that turned black (Table 3). Differences were observed when treatments were performed at $<24$ and $72-96 \mathrm{~h}$ after parasitization. In the first case, the number of parasitized host eggs treated with endosulfan was significantly smaller than those treated with lambdacyhalothrin. In the second case (72-96 h after parasitism), the number of parasitized host eggs was significantly higher when deltamethrin was applied in comparison with basic copper sulphate (Table 3).

Adult emergence rates of the parasitoids from the first four treatments (chemical insecticides) were significantly inferior to the control values (Table 4). The adult emergence rates of $T$. cordubensis were reduced to near zero by endosulfan. Lambda-cyhalothrin reduced the emergence rate by approximately $40 \%$, and deltamethrin reduced it by approximately $26 \%$. 
TABLE 2. Mean $( \pm \mathrm{SD})$ of the duration of development (days) when seven pesticides were applied on different phases of the development of $T$. cordubensis

\begin{tabular}{lcccccc}
\hline Pesticide & $<24$ & $24-48$ & $48-72$ & $72-96$ & $120-144$ & $192-216$ \\
\hline Trichlorfon & $13.1 \pm 0.7 \mathrm{a}$ & $13.1 \pm 0.6 \mathrm{a}$ & $13.2 \pm 0.6 \mathrm{a}$ & $13.0 \pm 0.8 \mathrm{a}$ & $13.1 \pm 0.9 \mathrm{a}$ & $13.0 \pm 1.0 \mathrm{a}$ \\
Endosulfan & $14.4 \pm 1.2^{*}$ & $14.0 \pm 1.0^{*}$ & $14.5 \pm 0.7^{*}$ & $14.3 \pm 1.0^{*}$ & $15.0 \pm 0.0^{*}$ & - \\
Deltamethrin & $13.1 \pm 0.6 \mathrm{a}$ & $13.3 \pm 0.6 \mathrm{a}$ & $13.3 \pm 0.6 \mathrm{a}$ & $13.2 \pm 0.8 \mathrm{a}$ & $13.1 \pm 0.8 \mathrm{a}$ & $13.4 \pm 0.8 \mathrm{a}$ \\
Lambda-cyhalothrin & $13.1 \pm 0.8 \mathrm{a}$ & $13.0 \pm 0.7 \mathrm{a}$ & $13.5 \pm 0.5 \mathrm{a}$ & $13.2 \pm 0.6 \mathrm{a}$ & $13.3 \pm 0.4 \mathrm{a}$ & $13.5 \pm 0.5 \mathrm{a}$ \\
Bacillus thuringiensis & $13.0 \pm 0.7 \mathrm{a}$ & $13.1 \pm 0.7 \mathrm{a}$ & $13.5 \pm 0.5 \mathrm{a}$ & $13.3 \pm 0.9 \mathrm{a}$ & $13.3 \pm 0.9 \mathrm{a}$ & $13.4 \pm 0.7 \mathrm{a}$ \\
$\begin{array}{l}\text { Acetamide+ } \\
\text { dithiocarbamete }\end{array}$ & $13.0 \pm 0.7 \mathrm{a}$ & $13.1 \pm 0.8 \mathrm{a}$ & $13.0 \pm 0.9 \mathrm{a}$ & $13.0 \pm 0.9 \mathrm{a}$ & $13.0 \pm 0.9 \mathrm{a}$ & $13.0 \pm 0.9 \mathrm{a}$ \\
Basic copper sulphate & $13.0 \pm 0.7 \mathrm{a}$ & $13.1 \pm 0.8 \mathrm{a}$ & $13.3 \pm 0.9 \mathrm{a}$ & $13.3 \pm 0.9 \mathrm{a}$ & $13.3 \pm 0.8 \mathrm{a}$ & $13.3 \pm 0.9 \mathrm{a}$ \\
Control & $13.0 \pm 0.7 \mathrm{a}$ & $12.9 \pm 0.8 \mathrm{a}$ & $13.1 \pm 0.7 \mathrm{a}$ & $13.1 \pm 0.7 \mathrm{a}$ & $13.0 \pm 0.7 \mathrm{a}$ & $13.4 \pm 0.7 \mathrm{a}$ \\
ANOVA & & & & & & \\
$F$ & 0.06 & 0.06 & 0.70 & 0.34 & 0.41 & 0.90 \\
df & 6 & 6 & 6 & 6 & 6 & 6 \\
$P$ & $>0.05$ & $>0.05$ & $>0.05$ & $>0.05$ & $>0.05$ & $>0.05$ \\
\hline
\end{tabular}

ANOVA $F$, df and $P$-values.

Means in each column followed by a different letter are significantly different $(P<0.05$, Student-NewmanKeuls test).

* Sample size was too small to include in analysis.

TABLE 3. Mean $( \pm \mathrm{SD})$ number of parasitized host eggs that turned black when seven pesticides were applied on different phases of the development of T. cordubensis

\begin{tabular}{|c|c|c|c|c|c|c|}
\hline Pesticide & $<24$ & $24-48$ & $48-72$ & $72-96$ & $120-144$ & $192-216$ \\
\hline Trichlorfon & $218.5 \pm 40.6 \mathrm{ab}$ & $215.8 \pm 38.1 \mathrm{a}$ & $214.2 \pm 61.3 \mathrm{a}$ & $239.8 \pm 36.4 a b$ & $231.3 \pm 46.7 \mathrm{a}$ & $224.2 \pm 57.2 \mathrm{a}$ \\
\hline Endosulfan & $200.4 \pm 44.3 \mathrm{a}$ & $228.0 \pm 42.8 \mathrm{a}$ & $233.0 \pm 48.1 \mathrm{a}$ & $230.9 \pm 29.2 \mathrm{ab}$ & $228.3 \pm 35.9 \mathrm{a}$ & $225.9 \pm 52.0 \mathrm{a}$ \\
\hline Deltamethrin & $212.2 \pm 46.5 \mathrm{ab}$ & $243.2 \pm 42.9 \mathrm{a}$ & $241.0 \pm 37.2 \mathrm{a}$ & $262.7 \pm 29.4 a$ & $237.9 \pm 38.1 \mathrm{a}$ & $225.8 \pm 50.3 \mathrm{a}$ \\
\hline $\begin{array}{l}\text { Lambda- } \\
\text { cyhalothrin } \\
\text { Bacillus }\end{array}$ & $244.6 \pm 27.0 \mathrm{~b}$ & $236.9 \pm 35.5 \mathrm{a}$ & $229.0 \pm 57.0 \mathrm{a}$ & $254.3 \pm 48.2 \mathrm{ab}$ & $215.0 \pm 40.9 \mathrm{a}$ & $230.8 \pm 33.2$ \\
\hline $\begin{array}{l}\text { thuringiensis } \\
\text { Acetamide+ }\end{array}$ & $229.3 \pm 40.8 \mathrm{ab}$ & $216.5 \pm 45.0 \mathrm{a}$ & $241.0 \pm 31.3 \mathrm{a}$ & $221.0 \pm 51.7 \mathrm{ab}$ & $240.7 \pm 39.7 \mathrm{a}$ & $234.7 \pm 52.7 \mathrm{a}$ \\
\hline $\begin{array}{l}\text { dithio- } \\
\text { carbamete }\end{array}$ & $232.7 \pm 40.8 \mathrm{ab}$ & $240.2 \pm 38.3 \mathrm{a}$ & $235.9 \pm 35.2 \mathrm{a}$ & $244.3 \pm 36.4 \mathrm{ab}$ & $241.9 \pm 39.2 \mathrm{a}$ & $233.5 \pm 42.0 \mathrm{a}$ \\
\hline $\begin{array}{l}\text { Basic copper } \\
\text { sulphate }\end{array}$ & $211.8 \pm 35.1 \mathrm{ab}$ & $212.5 \pm 42.3 \mathrm{a}$ & $226.0 \pm 45.0 \mathrm{a}$ & $219.6 \pm 63.0 \mathrm{~b}$ & $243.0 \pm 37.7 \mathrm{a}$ & $239.8 \pm 45.1 \mathrm{a}$ \\
\hline Control & $232.2 \pm 27.7 \mathrm{ab}$ & $233.0 \pm 49.3 \mathrm{a}$ & $210.9 \pm 32.1 \mathrm{a}$ & $238.0 \pm 43.6 \mathrm{ab}$ & $233.2 \pm 40.1 \mathrm{a}$ & $224.2 \pm 52.0 \mathrm{a}$ \\
\hline $\begin{array}{l}\text { ANOVA } \\
F\end{array}$ & 28 & & & & 0 & (0) \\
\hline $\mathrm{df}$ & 7 & 7 & 7 & 7 & 7 & 7 \\
\hline$P$ & $<0.01$ & $>0.05$ & $>0.05$ & $<0.05$ & $>0.05$ & $>0.05$ \\
\hline
\end{tabular}

ANOVA $F$, df and $P$-values.

Means in each column followed by a different letter are significantly different $(P<0.05$, Student-NewmanKeuls test).

Basic copper sulphate, when applied 24-48, 72-96, 120-144 and 192-216 h after parasitis m differed significantly from the control values, with a similar effect to trichlorfon (Table 4).

The longevity of adult progeny was very short when endosulfar or trichlorfon $(<1$ and $<2$ days, respectively) were applied. With the other products, longevity varied from 10 to 16 days without significant differences among pesticides. Aside from organophosphate and organochlorin e insecticides, only lambda-cyhalothrin, applied 72-96 h after parasitization, significantly reduced longevity when compared with the control (Table 5). 
TABLE 4. Adult emergence rates $( \pm \mathrm{SD})$ when seven pesticides were applied on different phases of the development of T. cordubensis

\begin{tabular}{lcccccc}
\hline Pesticide & $<24$ & $24-48$ & $48-72$ & $72-96$ & $120-144$ & $192-216$ \\
\hline Trichlorfon & $91.0 \pm 05.3 \mathrm{a}$ & $92.6 \pm 03.0 \mathrm{a}$ & $89.4 \pm 05.7 \mathrm{a}$ & $87.7 \pm 08.8 \mathrm{a}$ & $88.7 \pm 05.1 \mathrm{a}$ & $91.4 \pm 04.3 \mathrm{a}$ \\
Endosulfan & $00.4 \pm 00.8 \mathrm{~b}$ & $00.1 \pm 00.3 \mathrm{~b}$ & $00.0 \pm 00.1 \mathrm{~b}$ & $00.2 \pm 00.3 \mathrm{~b}$ & $00.1 \pm 00.4 \mathrm{~b}$ & $00.0 \pm 00.0 \mathrm{~b}$ \\
Deltamethrin & $74.5 \pm 04.8 \mathrm{c}$ & $69.0 \pm 09.3 \mathrm{c}$ & $70.2 \pm 08.7 \mathrm{c}$ & $65.3 \pm 11.3 \mathrm{c}$ & $65.8 \pm 13.7 \mathrm{c}$ & $67.0 \pm 11.5 \mathrm{c}$ \\
Lambda-cyhalothrin & $62.4 \pm 13.6 \mathrm{~d}$ & $56.8 \pm 15.0 \mathrm{~d}$ & $57.3 \pm 15.5 \mathrm{~d}$ & $51.2 \pm 22.9 \mathrm{c}$ & $45.7 \pm 20.3 \mathrm{~d}$ & $51.8 \pm 14.9 \mathrm{~d}$ \\
Bacillus thuringiensis & $96.1 \pm 01.4 \mathrm{e}$ & $95.5 \pm 01.6 \mathrm{e}$ & $96.5 \pm 01.7 \mathrm{e}$ & $95.6 \pm 02.6 \mathrm{~d}$ & $96.4 \pm 01.2 \mathrm{e}$ & $95.5 \pm 02.8 \mathrm{e}$ \\
Acetamide+ & & & & & & \\
$\quad$ dithiocarbamete & $95.4 \pm 01.8 \mathrm{e}$ & $96.2 \pm 02.2 \mathrm{e}$ & $96.7 \pm 01.5 \mathrm{e}$ & $96.0 \pm 01.3 \mathrm{~d}$ & $95.7 \pm 01.7 \mathrm{e}$ & $95.3 \pm 01.8 \mathrm{e}$ \\
Basic copper sulphate & $94.3 \pm 02.1 \mathrm{e}$ & $93.2 \pm 02.4 \mathrm{a}$ & $94.4 \pm 02.2 \mathrm{e}$ & $91.1 \pm 07.9 \mathrm{a}$ & $90.0 \pm 06.3 \mathrm{a}$ & $90.4 \pm 04.7 \mathrm{a}$ \\
Control & $96.0 \pm 01.3 \mathrm{e}$ & $95.9 \pm 02.1 \mathrm{e}$ & $91.4 \pm 02.4 \mathrm{e}$ & $95.4 \pm 02.0 \mathrm{~d}$ & $96.1 \pm 01.5 \mathrm{e}$ & $95.2 \pm 02.0 \mathrm{e}$ \\
& & & & & & \\
ANOVA & & & & & & \\
$F$ & 808.7 & 752.3 & 677.9 & 307.9 & 385.3 & 610.2 \\
df & 7 & 7 & 7 & 7 & 7 & 7 \\
$P$ & $<0.001$ & $<0.001$ & $<0.001$ & $<0.001$ & $<0.001$ & $<0.001$ \\
\hline
\end{tabular}

ANOVA $F$, df and $P$-values.

Means in each column followed by a different letter are significantly different $(P<0.05$, Student-NewmanKeuls test).

TABLE 5. Mean ( \pm SD) adult progeny longevity (days) when seven pesticides were applied on different phases of the development of $T$. cordubensis

\begin{tabular}{|c|c|c|c|c|c|c|}
\hline Pesticide & $<24$ & $24-48$ & $48-72$ & $72-96$ & $120-144$ & $192-216$ \\
\hline Trichlorfon & $01.7 \pm 0.8 \mathrm{a}$ & $01.8 \pm 0.7 \mathrm{a}$ & $01.7 \pm 0.6 \mathrm{a}$ & $01.5 \pm 1.1 \mathrm{a}$ & $01.9 \pm 0.7 \mathrm{a}$ & $02.0 \pm 0.4 \mathrm{a}$ \\
\hline Endosulfan & $<1^{*}$ & $<1^{*}$ & $<1^{*}$ & $<1^{*}$ & $<1^{*}$ & - \\
\hline Deltamethrin & $12.5 \pm 5.3 b$ & $13.2 \pm 5.2 \mathrm{~b}$ & $13.3 \pm 6.1 \mathrm{~b}$ & $13.4 \pm 5.8 \mathrm{bc}$ & $12.9 \pm 5.1 \mathrm{~b}$ & $12.3 \pm 4.4 \mathrm{~b}$ \\
\hline Lambda-cyhalothrin & $11.1 \pm 4.8 b$ & $11.3 \pm 4.9 \mathrm{~b}$ & $11.8 \pm 4.4 \mathrm{~b}$ & $11.0 \pm 4.9 b$ & $10.6 \pm 3.9 b$ & $11.7 \pm 4.6 \mathrm{~b}$ \\
\hline Bacillus thuringiensis & $15.7 \pm 6.7 b$ & $14.4 \pm 6.9 \mathrm{~b}$ & $15.7 \pm 6.8 b$ & $16.0 \pm 6.5 b c$ & $16.2 \pm 7.1 \mathrm{~b}$ & $15.5 \pm 6.2 b$ \\
\hline Acetamide + & & & & & & \\
\hline dithiocarbamete & $14.8 \pm 0.7 b$ & $15.3 \pm 7.6 \mathrm{~b}$ & $15.6 \pm 6.6 \mathrm{~b}$ & $15.5 \pm 6.5 \mathrm{bc}$ & $15.8 \pm 7.3 b$ & $16.3 \pm 7.1 \mathrm{~b}$ \\
\hline Basic copper sulphate & $15.5 \pm 6.7 \mathrm{~b}$ & $14.6 \pm 6.1 \mathrm{~b}$ & $14.3 \pm 5.7 b$ & $16.3 \pm 7.5 b c$ & $15.1 \pm 6.8 b$ & $16.3 \pm 6.6 b$ \\
\hline Control & $16.5 \pm 7.0 \mathrm{~b}$ & $15.4 \pm 7.2 \mathrm{~b}$ & $15.8 \pm 7.2 \mathrm{~b}$ & $16.9 \pm 7.5 \mathrm{c}$ & $16.2 \pm 8.9 \mathrm{~b}$ & $15.3 \pm 6.6 b$ \\
\hline \multicolumn{7}{|l|}{ ANOVA } \\
\hline$F$ & 23.57 & 19.77 & 22.41 & 25.36 & 20.81 & 23.96 \\
\hline $\mathrm{df}$ & 6 & 6 & 6 & 6 & 6 & 6 \\
\hline$P$ & $<0.001$ & $<0.001$ & $<0.001$ & $<0.001$ & $<0.001$ & $<0.001$ \\
\hline
\end{tabular}

ANOVA $F$, df and $P$-values.

Means in each column followed by a different letter are significantly different $(P<0.05$, Student-NewmanKeuls test).

* Sample size was too small to include in analysis.

\section{Bioassay 2}

In all tests, including the control, the mortality of the females increased with time.

Endosulfan was the most quickly and highly toxic pesticide for adults of $T$. cordubensis, causing 100\% mortality. Trichlorfon gave slower, but similar results (Table 6).

Both pyrethroids (deltamethrin and lambda-cyhalothrin) reduced the parasitoid population by approximately $25 \%, 48 \mathrm{~h}$ after the first contact with pesticide. Comparing these results with those obtained for the other products, we observed some significant differences between pyrethroids and the other treatments (Table 6).

Bacillus thuringiensis and the two fungicides, acetamide + dithiocarbamete and basic copper sulphate, did not cause significant mortality in $T$. cordubensis as compared with the control. Only acetamide + dithiocarbamete caused a greater mortality $48 \mathrm{~h}$ after the first contact with the pesticide, when treated eggs were given to parasitoids immediately (Table 6). 
TABLE 6. Mortality rates $( \pm \mathrm{SD})$ when seven pesticides were applied on adults of $T$. cordubensis

\begin{tabular}{|c|c|c|c|c|c|c|}
\hline \multirow[b]{2}{*}{ Pesticide } & \multicolumn{3}{|c|}{$0 \mathrm{~h}$ after treatment } & \multicolumn{3}{|c|}{$24 \mathrm{~h}$ after treatment } \\
\hline & $6 \mathrm{~h}$ & $24 \mathrm{~h}$ & $48 \mathrm{~h}$ & $6 \mathrm{~h}$ & $24 \mathrm{~h}$ & $48 \mathrm{~h}$ \\
\hline Trichlorfon & $29.1 \pm 39.3 \mathrm{a}$ & $94.8 \pm 14.1 \mathrm{a}$ & $100.0 \pm 00.0 \mathrm{a}$ & $40.7 \pm 47.9 a$ & $89.2 \pm 20.6 \mathrm{a}$ & $99.7 \pm 01.5 \mathrm{a}$ \\
\hline Endosulfan & $100.0 \pm 00.0 \mathrm{~b}$ & $100.0 \pm 00.0 \mathrm{a}$ & $100.0 \pm 00.0 \mathrm{a}$ & $98.0 \pm 05.3 b$ & $100.0 \pm 00.0 \mathrm{a}$ & $100.0 \pm 00.0 \mathrm{a}$ \\
\hline Deltamethrin & $06.4 \pm 07.4 \mathrm{c}$ & $15.5 \pm 11.9 b$ & $17.5 \pm 11.9 b$ & $05.1 \pm 04.9 \mathrm{c}$ & $18.7 \pm 14.1 b$ & $20.6 \pm 14.9 b$ \\
\hline Lambda-cyhalothrin & $06.3 \pm 08.9 \mathrm{c}$ & $17.9 \pm 18.8 b$ & $21.4 \pm 19.9 b$ & $06.7 \pm 06.9 \mathrm{c}$ & $19.2 \pm 13.9 b$ & $26.3 \pm 20.0 b$ \\
\hline Bacillus thuringiensis & $00.3 \pm 01.5 \mathrm{c}$ & $03.7 \pm 06.2 \mathrm{c}$ & $04.2 \pm 07.3 c$ & $00.7 \pm 03.0 \mathrm{c}$ & $04.4 \pm 07.0 \mathrm{c}$ & $05.9 \pm 07.6 \mathrm{c}$ \\
\hline 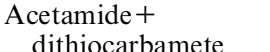 & $003+015 c$ & $031+015 c$ & $236+394 b$ & $003+015 c$ & $041+056 c$ & $063+087 \mathrm{c}$ \\
\hline Basic copper sulphate & $00.0 \pm 00.0 \mathrm{c}$ & $02.7 \pm 07.2 \mathrm{c}$ & $04.7 \pm 09.8 \mathrm{c}$ & $00.3 \pm 01.5 \mathrm{c}$ & $05.3 \pm 05.8 \mathrm{c}$ & $08.6 \pm 09.4 \mathrm{c}$ \\
\hline Control & $00.0 \pm 00.0 \mathrm{c}$ & $00.3 \pm 01.3 c$ & $03.5 \pm 04.7 \mathrm{c}$ & $00.3 \pm 01.5 \mathrm{c}$ & $02.8 \pm 05.3 \mathrm{c}$ & $04.6 \pm 05.3 \mathrm{c}$ \\
\hline ANOVA & & & & & & \\
\hline$F$ & 112.5 & 318.8 & 133.6 & 72.1 & 249.2 & 302.2 \\
\hline df & 7 & 7 & 7 & 7 & 7 & 7 \\
\hline$P$ & $<0.001$ & $<0.001$ & $<0.001$ & $<0.001$ & $<0.001$ & $<0.001$ \\
\hline
\end{tabular}

ANOVA $F$, df and $P$-values.

Means in each column followed by a different letter are significantly different $(P<0.05$. Student-NewmanKeuls test).

Results show that the tested pesticides have a high residual effect, since the mortality values were similar when the parasitoids contacted with the pesticide immediately or $24 \mathrm{~h}$ after the treatments.

\section{DISCUSSION}

Of the pesticides evaluated in this study, the organochlorine and organophosphat e insecticides were the most toxic to $T$. cordubensis. However, trichlorfon was less toxic than endosulfan. The pyrethroids were less harmful, with deltamethrin being less toxic than lambda-cyhalothrin. Bacillus thuringiensis and the two fungicides were not harmful to T. cordubensis. These pesticides did not affect parameters such as the duration of development and the number of parasitized host eggs that turned black before treatment.

A negative effect was observed on both the adult emergence rates and the longevity of adult progeny (Bioassay 1) when endosulfan and trichlorfon were applied. The first parameter was also influenced by the pyrethroids. These results indicate that the egg chorion of E. kuehniella did not protect the parasitoid.

As observed for T. cordubensis, a very low adult emergence rate of T. australicum Girault and Trichogrammatoide a armigera Nagaraja has been reported by Dutt and Somchoudhury (1986) and Jalali and Singh (1993), respectively, when endosulfan was applied to immature forms of the parasitoids. Contrary to our findings, endosulfan sprays have been found to be of low toxicity to T. pretiosum (Riley) (Hohmann, 1991, 1993), to T. chilonis Ishi (Santharam \& Kumaraswami, 1985; Kumar et al., 1994) and to T. perkinsi Girault (Dutt \& Somchoudhury, 1986).

The emergence rate of adults was reduced significantly by the pyrethroids deltamethrin and lambda-cyhalothrin . Kring and Smith (1995), when studying the effects of cyhalothrin in $T$. pretiosum, also observed a reduction in the emergence rate. Sterk et al. (1999) found similar results when applying lambda-cyhalothrin to pupae of different species of Trichogramma. On the other hand Hohmann (1991, 1993) obtained different results with T. pretiosum, as did Jalali and Singh (1993) with Trichogrammatoide a armigera and Kuman et al. (1994) with T. cholonis when deltamethrin was applied.

Trichlorfon did not affect the adult emergence rate of $T$. cordubensis, but reduced adult longevity greatly when treatment was performed on preimaginal stages. This reduction in 
longevity will therefore in turn cause a reduction in the number of hosts parasitized by these wasps.

Bacillus thuringiensis did not affect the biological parameters of $T$. cordubensis measured in this study. Sterk et al. (1999) found similar results for a long list of beneficial organisms.

Fungicides were found to be safe to all stages of T. cordubensis, as suggested by Jalali and Singh (1993) and Sterk et al. (1999) for other fungicides applied to beneficial organisms. Results show that these fungicides can be used simultaneously with $T$. cordubensis, allowing the development of integrated pest management programmes in the Azores.

The mortality of adults was not affected by the pyrethroids after $6 \mathrm{~h}$ of contact. However, when this period is longer (i.e. 24 or $48 \mathrm{~h}$ ) the mortality of the parasitoids is significantly higher than the control values (Bioassay 2). Previous studies had also demonstrated that these pyrethroids can be very dangerous for Trichogrammatoidea armigera, T. chilonis and T. pretiosum (Jalali \& Singh, 1993; Kumar et al., 1994; Branco \& França, 1995). Endosulfan was very harmful to adult $T$. cordubensis, with very high mortality values after a short period of contact (Bioassay 2). This also has been reported for T. evanescens Westwood by Chan (1978), for T. cacaecia Marchal by Hassan et al. (1983) and for Trichogrammatoidea armigera by Jalali and Singh (1993). However, this effect was more moderate in studies of T. pretiosum (Jacobs et al., 1984) and T. australicum (Dutt \& Somchoudhury, 1986).

The mortality of the adults was similar when parasitoids contacted immediately or $24 \mathrm{~h}$ after the treatments, indicating that all pesticides had a high residual effect.

Of the seven pesticides tested here, endosulfan was the most harmful to the preimaginal developmental stages of $T$. cordubensis. Therefore, its use should be avoided when this species is part of an integrated pest control programme. Nevertheless, additional studies are required to determine whether a low concentration of these pesticides can be used safely in agricultural pest control without affecting natural enemies of the pests.

\section{ACKNOWLEDGEMENTS}

This research was effectuated on CIRN (Centro para a Investigação dos Recursos Naturais) and financially supported by the Universidade dos Açores.

\section{REFERENCES}

Branco, M.C. \& FranÇA, F.H. (1995) Impacto de inseticidas e bioinseticidas sobre adultos de Trichogramma pretiosum. Horticultura Brasileira 13, 199-201.

Chan, K.C. (1978) The effect of some insecticides on the common Trichogramma (T. evanescens Westwood). Grad I Lozaraska Nauka 15, 73-79.

Driesche, R.G. van \& Bellows, T.S., JR. (1996) Biological Control. Chapman \& Hall, New York, NY, USA.

DutT, N. \& Somchoudhury, A.K. (1986) Mortality response of immature and adult forms of Trichogramma perkinsi Girault and Trichogramma australicum Girault to few insecticides. Indian Journal of Entomology 48, 23-31.

Garcia, P. (1995) Trichogramma cordubensis Vargas \& Cabello (Hym., Trichogrammatidae) na ilha de S. Miguel (Açores): Aspectos de Sistemática e Ecologia. Dissertation, Universidade dos Açores, Açores.

Garcia, P., Oliveira, L. \& TAvares, J. (1994) Trichogramma cordubensis (Hym., Trichogrammatidae): a dynamics study of an Azorean population, in Trichogramma and Other Egg Parasitoids (WAJNBERG, E., Eds) 4th International Symposium. Les Colloques de l'INRA 73, 189-192.

Gullan, P.J. \& Cranston, P.S. (1992) The Insects: An Outline of Entomology. Chapman \& Hall, New York, NY, USA.

Hassan, S.A., Bigler, F., Bogenschütz, H., Brown, J.U., Firth, S.J., Huang, P., Ledieu, M.S., Naton, E., Oomen, P.A., Overmeer, W.P.J., Rieckmann, W., Samsoe-Petersen, L., Viggianni, G. \& Van Zon, A.Q. (1983) Results of the second joint pesticide testing programme by the IOBC/WPRS Working Group 'Pesticides and Beneficial Arthopods'. Zeitschrift für Angewandte Entomologie 95, 151-158.

Hohmann, C.L. (1991) Efeito de diferentes insecticidas sobre a emergência de Trichogramma pretiosum (Hymenoptera: Trichogrammatidae). Anais da Sociedade Entomológica do Brasil 20, 59-65.

Hohmann, C.L. (1993) Efeito de alguns insecticidas sobre adultos de Trichogramma pretiosum RILEY. Anais da Sociedade Entomológica do Brasil 22, 563-568.

Jacobs, R.J., Kouskolekas, C.A. \& Gross, H.R., JR. (1984) Responses of Trichogramma pretiosum 
(Hymenoptera: Trichogrammatidae) to residues of permethrin and endosulfan. Environmental Entomology 13, 355-358.

JALALI, S.K. \& SingH, S.P. (1993) Susceptibility of various stages of Trichogrammatoide a armigera Nagaraja to some pesticides and effect of residues on survival and parasitizing ability. Biocontrol Science and Technology 3, 21-27.

Kring, T.J. \& Smith, T.B. (1995) Trichogramma pretiosum efficacy in cotton under Bt-insecticides combinations. Cotton Insect Research and Control Conference, pp. 856-857.

Kumar, M.G., Sundarabadu, P.C. \& Edward, Y.S.J.T. (1994) Contact toxicity of insecticides to ecotypes of egg parasitoid Trichogramma chilonis Ishii. Madras Agriculture Journal 81, 437-439.

Norusis, M.J. (1994) SPSS Advanced Statistics 6.1. SPSS Inc., USA.

Santharam, G. \& Kumaraswami, T. (1985) Effect of some insecticides on the emergence of the parasitoid, Trichogramma chilonis Ishii (Hymenoptera: Trichogrammatidae). Entomon 10, 47-48.

Sterk, G., Hassan, S.A., Baillod, M., Bakker, F., Bigler, F., Blümel, S., Bogenschütz, H., Boller, E., Bromand, B., Brun, J., Calis, J.N.M., Coremans-Pelseneer, J., Duso, C., Garrido, A., Grove, A., Heimbach, U., Hokkanen, H., Jacas, J., Lewis, G., Moreth, L., Polgar, L., Roversti, L., SamsoePetersen, L., Sauphanor, B., Schaub, L., Stäubli, A., Tuset, J.J., Vainio, A., Van de Veire, M., Viggiani, G., Viñuela, E. \& Vogt, H. (1999) Results of the seventh joint pesticide testing programme carried out by the IOBC/WPRS-Working Group 'Pesticides and beneficial organisms'. Biocontrol 44, 99-117.

Tavares, J. \& Veira, V. (1992) Produção em massa de Ephestia kuehniella Zeller (Lep., Pyralidae) IVTécnicas de recolha dos adultos e ovos. Açoreana 7, 461-470.

ZAR, J.H. (1996) Biostatistical Analysis. Prentice-Hall International Editions, London, UK. 